\title{
Steroids in neuroinfection
}

\author{
Esteróides em neuroinfecção
}

Ronaldo Abraham

\begin{abstract}
The consequences of inflammatory response are primarily responsible for morbimortality in bacterial meningitis. Early use of steroids in these cases can reduce mortality and hearing loss and improve functional outcome without causing significant side effects. The formal recommendation towards pneumoccocal meningitis is being extended to other forms of Bacterial Meningitis. The same thought can be applied to tuberculous meningitis. In neurocysticercosis and neuroschistosomiasis steroids are more useful than parasiticides in most cases. Despite the evidence favoring the use of steroids in herpes simplex encephalitis, it is not sufficient to definitely support such indication. Among the opportunistic infections that affect AIDS patients, neurotoxoplasmosis and progressive multifocal leukoencephalopaty are those most often considered for the use of steroids; steroids are safe to use, but no definite benefit could be demonstrated in both conditions.
\end{abstract}

Keywords: steroids, bacterial meningitis, tuberculosis, neuroparasitosis, AIDS.

\section{RESUMO}

As consequências da resposta inflamatória são as grandes responsáveis pela morbimortalidade das meningites bacterianas. 0 uso precoce de esteróides nestes casos pode reduzir a mortalidade e a perda auditiva, além de atenuar as consequências a longo prazo deste grupo de doenças, sem causar efeitos colaterais importantes. A recomendação formal de seu uso na meningite pneumocócica tem sido ampliada para outras formas de meningite bacteriana. 0 mesmo raciocínio pode ser aplicado para a Meningite tuberculosa. Na neurocisticercose e na neuroesquistossomose, os esteróides são mais úteis que as drogas parasiticidas na maior parte dos casos. Apesar de evidências a favor do seu uso na Encefalite Herpética, não existe ainda suporte definitivo para esta recomendação. Entre as infecções oportunísticas que ocorrem nos pacientes com AIDS, a Neurotoxoplasmose e a leucoencefalopatia multifocal progressiva são as mais frequentemente relacionadas com o uso dos esteróides; seu uso tem se mostrado seguro, mas seus benefícios não parecem bem estabelecidos em ambas as condições.

Palavras-Chave: esteróides, meningite bacteriana, tuberculose, neuroparasitoses, AIDS.

Steroids are hormone products of the adrenal cortex with numerous effects on endocrine and nonendocrine functions. Biologically active analog synthesis, especially glucocorticoids, has allowed their use in a wide range of different diseases. At doses that exceed normal daily production levels these hormones exert a potent antiinflammatory and immunosuppressive action. Steroids can suppress inflammation that occurs in response to variable inciting events. Although their use does not address the underlying disease, inflammation suppression has a huge clinical utility. The antiinflammatory and immunosuppressive actions cannot be split but even so some infectious diseases have clear indication for the use of steroids ${ }^{1}$. The inflammatory response that occurs in meningeal space is mediated by proinflammatory factors such as interleukin-1 and tumor necrosis factor, released by pathogen lysis induced by antibiotic treatment. The consequences of this inflammatory response are primarily responsible for morbimortality in bacterial meningitis and can be attenuated by steroids use. Other infectious diseases affecting the central nervous system, such as neurotuberculosis, herpes simplex encephalitis, neurocysticercosis, neuroschistosomiasis and AIDS related conditions have been widely treated with steroids in an adjunctive way. In some cases their use is crucial and more important than the treatment of the underlying disease itself. The potential risk of side effects makes the decision to institute steroid therapy a careful consideration in each patient, with special concern for treatment duration. Some of the long term adverse events of steroids use include gastrointestinal bleeding, myopathy, bone loss, hyperglycemia and premature cataract.

\section{Bacterial meningitis}

Supporting treatment with steroids has been widely applied in bacterial meningitis (BM) since 1988, when Lebel $e t$ $a l$. strongly suggested its use ${ }^{2}$. The early use of this medicine has been related to a better prognosis, especially in those cases caused by Streptococcus pneumoniae ${ }^{3}$. It can reduce mortality and hearing loss ${ }^{4}$ and improve functional outcome $e^{5}$ without causing significant side effects. This recommendation was extended to BM caused by Haemophilus influenzae;

Medicine Department, Taubaté University, São Paulo SP, Brasil.

Correspondence: Ronaldo Abraham; Rua Dr. Souza Alves 35; 12020-030 Taubaté São Paulo SP - Brasil; Email: rnabraham@uol.com.br 
this pathogen has shown an important decrement in its incidence in the last decades after successful vaccination campaign implemented in our country. Some doubts remain about the use of steroids in cases of BM caused by Neisseria meningitidis. The lower rates of complications in these cases seem to raise difficulties in evaluating treatment efficacy, but the decrease in immune mediated arthritis with no definite harm in a series of patients may be a good indicative of its use $^{6}$. The use of steroids in meningoccocal meningitis seems acceptable, indeed. The statement of interrupting steroids as soon as another pathogen different from S. pneumoniae can be identified is now being reconsidered.

In the last years some studies developed in lower-income countries have shown intriguing results. One of them performed in a group of patients in which $90 \%$ were HIVpositive, showed that the use of steroids was not able to reduce mortality or morbidity ${ }^{7}$. Another study developed in Asia, where the main cause of meningitis is tuberculosis, found a significant beneficial effect in those patients when the correct microbiological diagnosis could be made ${ }^{8}$. These results raised the suspicion of its utility in these countries. Some points have to be stressed, such as previous clinical condition and access to adequate antibiotics, to better evaluate these results.

Currently, the dose regimen suggested includes Dexamethasone $10 \mathrm{mg}$ IV (or $0,15 \mathrm{mg} / \mathrm{kg} /$ day in children) at the time or immediately before the first dose of the chosen antibiotic, followed by the same drug every six hours for a total of four days ${ }^{5}$. Shorter periods of treatment have also shown to be effective. As Dexamethasone reduces blood-brain barrier permeability, it can interfere with antibiotic availability, reducing Vancomycin efficacy. Nowadays, we are observing a growing number of $S$. pneumoniae strains highly resistant to both Penicillin and Cephalosporins, leading to a more frequent use of Vancomycin. In a patient diagnosed with BM who was receiving Dexamethasone, Vancomycin should not be used as the sole antimicrobial agent ${ }^{9}$.

In summary, we can say that steroids are recommended in cases of BM caused by S. pneumoniae and H. influenzae, and their use is acceptable in cases of BM caused by $N$. meningitidis, provided that they do not delay the introduction of antibiotics, in patients with reasonable previous clinical conditions ${ }^{10}$. It must always be reminded that BM is a life-threatening condition requiring prompt diagnosis and treatment. Recent gastrointestinal bleeding, serious diabetes and shock are counterindications for the use of steroids.

\section{Tuberculous meningitis}

Tuberculosis remains a serious public health problem worldwide, affecting mainly the underdeveloped continents, causing millions of deaths annually. Meningitis is the most severe form of tuberculous infection causing death or permanent disability in more than half of the affected patients ${ }^{11}$.
Tuberculous meningitis (TbM) leads to severe meningeal inflammation with secondary cerebral tissue damage, what justifies the high incidence of fatal outcome and sequelae.

The use of steroids in TbM is not an innovation. The first important article about the theme was written in 1953 showing improvement in the poor prognosis reserved to these patients at that time ${ }^{12}$. Since then a great number of clinical studies has been developed, many of them suggesting a better outcome and faster recovery when steroids are added to the antituberculous chemotherapy. A thorough systematic review concluded that adjunctive steroids reduce mortality from $\mathrm{TbM}^{13}$. The mechanisms by which steroids improve outcome in TbM are still not fully understood. A fascinating hypothesis recently suggested lies in a genetic hint. The gene LTA4H that encodes leukotriene a4 hydrolase determines the balance of proinflammatory and antiinflammatory eicosanoids, and steroids could only reduce mortality in TbM patients who were major allele homozygous for that gene with the hyperinflammatory phenotype ${ }^{14}$. It could also explain why some patients get worse with this medicine, probably those with a hypoinflammatory phenotype. Moreover, it might impact the selection of candidates according to its genotype in future time ${ }^{15}$.

The steroid regimen used in TbM depends on the severity of the disease. The use of intravenous Dexamethasone for two to four weeks in tapering doses is recommended in the initial treatment, followed by a period of oral Dexamethasone ${ }^{16}$. The total length of treatment with steroids may reach eight weeks ${ }^{11}$.

\section{Herpes simplex encephalitis}

Herpes simplex (HSV) encephalitis is a viral infection that carries a high risk of mortality and morbidity even when adequately treated. HSV encephalitis is mostly related to HSV-1 virus and leads to hemorrhage, necrosis and extensive edema, especially at the temporal and frontal lobes. The intensity of the inflammatory reaction and the severity of the disease have led to the use of steroids in this situation, in order to reduce its consequences ${ }^{16}$. Furthermore, some authors suggested that steroids could control viral replication and restrict neuronal death, with better results if the treatment was delayed for three days ${ }^{17}$. Despite the evidence favoring the use of steroids in this life-threatening viral infection, it is not sufficient to definitely support its indication.

\section{Neuroparasitosis}

The adjunctive treatment with steroids has been highly recommended in the most important parasitic diseases with neurological involvement in our country. These are neurocysticercosis and neuroschistosomiasis, where their use is often more important than treating the underlying disease.

Neurocysticercosis is a disease with a variable inflammatory setting, ranging from asymptomatic cases to highly 
persistent inflammatory reactive cases, leading to the need of a potent anti-inflammatory drug. Steroids can be used to combat perilesional edema in degenerating cysts (figures 1 and 2) and are recommended during treatment with antiparasitic drugs, either albendazole or praziquantel, to decrease symptoms associated with the death of parasites ${ }^{18}$. Likewise antibiotics, steroids may negatively influence parasiticides efficacy. In order to attenuate these negative effects it has been suggested their use only at the first three days of treatment. However, the main indication of steroids in neurocysticercosis is related to the most severe and chronic forms of the disease, especially those cases with arachnoiditis, responsible for chronic lower limbs pain (figure 3), cranial nerve palsies, vasculitis and hydrocephalus (figure 4), among other symptoms. Its use has also been indicated in those cases treated with ventriculoperitoneal shunts, where it could decrease the frequency of blockages ${ }^{19}$.

Dexamethasone is the most frequently preferred steroid in these cases, in variable regimens. Doses may range from 4,5 to $32 \mathrm{mg}$ daily $^{18}$, depending on the inflammatory reaction intensity, but lower doses have shown to be equally

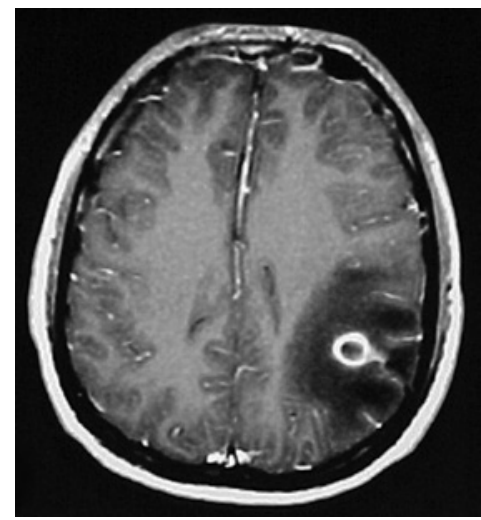

Figure 1. MRI T1-weighted sequence after gadolinium, axial section, showing a left parietal degenerating cyst surrounded by edema.

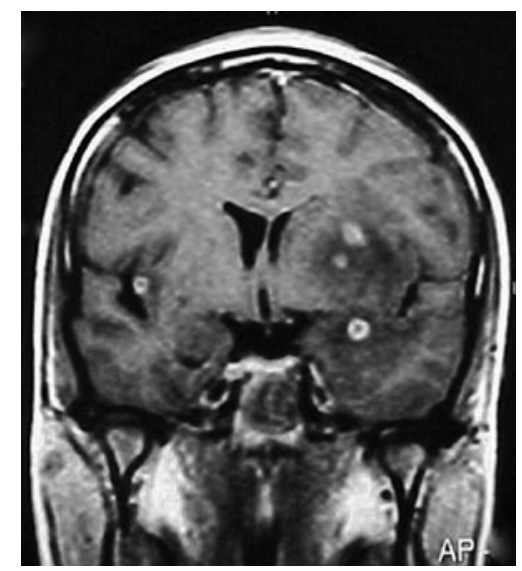

Figure 2. MRI T1-weighted sequence after gadolinium, coronal section, showing several simultaneously degenerating cysts, causing mass-effect. efficacious $^{20}$. Neurocysticercosis is accompanied by prolonged, sometimes recurrent, periods of inflammatory status leading to long-term treatments, and consequently accumulation of steroids side-effects. Hence, the need of a sparing steroid drug to be used for longer periods, such as dexchlorpheniramine ${ }^{21}$.

Similarly, in neuroschistosomiasis the use of steroids overcomes the use of specific antiparasitic drugs. The main neurological syndrome caused by Schistosoma mansoni is characterized by myeloradicular involvement of the lumbar region. Its symptoms are better treated with steroids, using IV Metylprednisolone for five days, followed by the use of Prednisone per os for as long as six months ${ }^{22}$.

\section{AIDS-related conditions}

Steroids have been used in some AIDS-related conditions, especially Toxoplasmosis and Progressive Multifocal Leukoencephalitis (PML).

Neurotoxoplasmosis (NT) is still a common occurrence in these patients, with a good prognosis in over fifty percent of the cases. In NT the rationale of steroids use is the mass-effect attributed to the extensive surrounding edema to the granulomas (figure 5) that can amplify many folds the

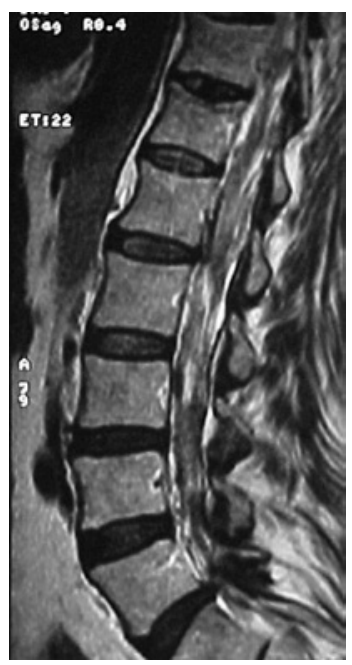

Figure 3. MRI FLAIR sequence, sagital section, showing adhesive arachnoiditis.

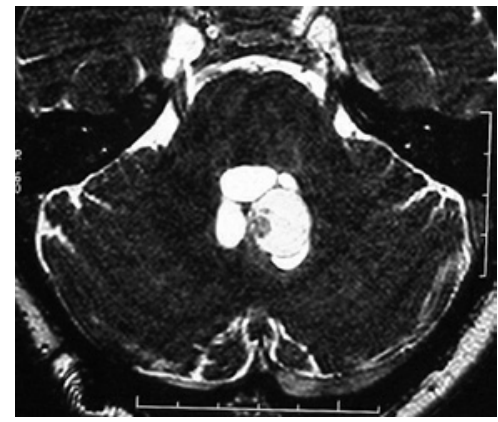

Figure 4. MRI FIESTA sequence, axial section, showing a cyst within the fourth ventricle, in a patient with hydrocephalus. 


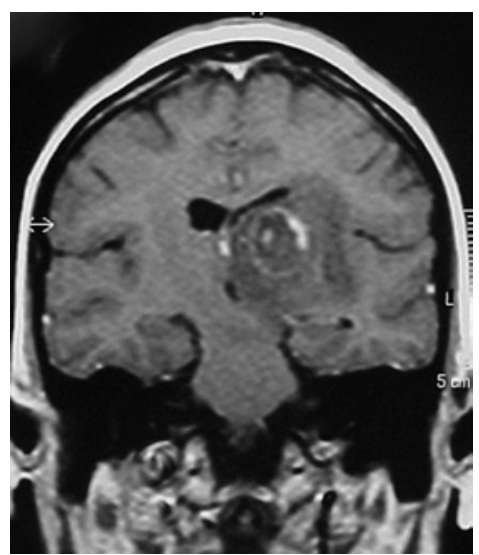

Figure 5. MRI T1-weighted sequence after gadolinium, coronal section, showing a deeply located granuloma, with ring enhancement and mass-effect.

original size of the lesion. In some extreme cases, usually related to profound immunossuppression, death is secondary to intracranial hypertension and brain herniation, and the use of steroids could be useful in reducing the edema and consequently the intracranial pressure ${ }^{23}$. Some doubts remain about their efficacy and safety in these cases. Although recognizing some limitations in the study, a recent research developed in five different French hospitals concluded that steroids are safe to use, but no definite benefit could be demonstrated from their use ${ }^{24}$.

Another important point related to the use of steroids in NT is the possibility of masking another disease. The primary lymphoma of CNS, and even other granulomas, can show improvement on the clinical ground and even on imaging follow-up, and the misdiagnosis of NT can delay the correct diagnosis ${ }^{25,26}$.

PML is an opportunistic infection caused by the JC virus that occurs in AIDS patients, nowadays most commonly in the context of the immune reconstitution inflammatory syndrome (IRIS). On the contrary of other opportunistic infections, PML has been keeping its incidence (up to five per cent of the patients with AIDS) $)^{27}$. The long-term survival rates of these patients have been modified by the use of current antiretroviral therapy. These agents seem to show no direct effect on JC virus replication, but the improvement in these cases seem related to a decline in some proteins and cytokines function known to transactivate the virus ${ }^{28}$.

The use of steroids for PML has been object of several studies, but remains controversial. An important retrospective review published in 2009 concludes that early and prolonged treatment with steroids may be useful in patients with PML-IRIS, mainly those who presented contrast enhanced lesions on neuroimaging studies. This characteristic is usually absent in classic PML. The regimen recommended starts with Methylprednisolone, $1 \mathrm{~g}$ intravenously per day, during 5 days, followed by Prednisone per os for 6 weeks.

\section{Conclusion}

The use of steroids constitutes a fundamental knowledge in the topics of therapeutics in neurology. They have been widely used in vascular, neoplastic, neuromuscular and inflammatory disorders, as well as in trauma, epilepsy and some forms of headache. Neuroinfectious diseases often demand their use, although sometimes controversial. It is important to know when and how steroids should be used.

\section{References}

1. Schimmer BP, Parker KL. Adrenocorticotropic hormone; Adrenocortical steroids and their synthetic analogs; Inhibitors of the synthesis and actions of adrenocortical hormones. In Goodman \& Gilman's The Pharmacological Basis of Therapeutics, 12th Ed New York, McGraw-Hill, 2011.

2. Lebel MH, Freij BJ, Syrogiannopoulos GA, et al. Dexamethasone therapy for bacterial meningitis: results of two double-blind, placebocontrolled trial. N Engl J Med 1988;319:964-971.

3. de Gans J, van de Beek D. Dexamethasone in adults with bacterial meningitis. N Engl J Med 2002;347:1549-1556.

4. Kasanmoentalib ES, Brouwer MC, van de Beek D. Update on bacterial meningitis: epidemiology, trial and genetic association studies.Curr Op Neurol 2013;26:282-288.

5. Bartt R. Acute bacterial and viral meningitis. Continuum Lifelong Learning Neurol 2012;18:1255-1270.

6. Heckenberg SGB, Brouwer MC, van der Ende A, van de Beek D. Adjunctive dexamethasone in adults with menongoccocal meningitis. Neurology 2012;79:1563-1569.

7. Scarborough M, Gordon SB, Whitty CJM, et al. Corticosteroids for Bacterial Meningitis in Sub-Saharan Africa. N Engl J Med 2007; 357:2441-2450.
8. Mai NTH, Chau TTH, Thwaites G, et al. Dexamethasone in Vietnamese Adolescents and Adults with Bacterial Meningitis. N Engl J Med 2007; 357:2431-2440.

9. Tunkel AR, Scheld WM. Corticosteroids for everyone with meningitis? N Engl J Med 2002;347:1613-1615.

10. Davis LE. Changing World of Acute Bacterial Meningitis. 65th American Academy Meeting, 2013.

11. Thwaites GE, Nguyen DB, Hoang TQ, et al. Dexamethasone for the treatment of tuberculous meningitis in adolescents and adults. N Engl J Med 2004;351:1741-1751.

12. Shane SJ, Riley C. Tuberculous meningitis: combined therapy with cortisone and antimicrobial agents. N Engl J Med 1953;249:829-834.

13. Prasad K, Singh MB. Corticosteroids for managing tuberculous meningitis. Cochrane Database Syst Rev 2008;1:CD002244.

14. Tobin DM, Roca FJ, Oh SF, et al. Host genotype-specific therapies can optimize the inflammatory response to mycobacterial infections. Cell 2012;148:434-446.

15. Thwaites GE. Advances in the diagnosis and treatment of tuberculous meningitis. Curr Op Neurol 2013;26:295-300.

16. Fitch MT, van de Beek D. Drug insight: steroids in CNS infectious 
diseases - new indications for an old therapy. Nat Clin Prac Neurol 2008;4:97-104.

17. Sergerie $Y$ et al. Delayed but not early glucocorticoid treatment protects the host during experimental herpes simplex encephalitis in mice. J Infect Dis 2007;195:1544-1549.

18. Garcia HH, Evans CAW, Nash TE, et al. Current consensus guidelines for treatment of neurocysticercosis. Clin Microbiol Rev 2002;15:747-756.

19. Roman RAS, Soto-Hernandez JL, Sotelo J. Effects of prednisone on ventriculoperitoneal shunt function in hydrocephalus secondary to cysticercosis: a preliminary study. J Neurosurg 1996;84:629-633.

20. Machado LR. Neurocisticercose - tratamento clínico (CD ROM) Curso PréCongresso XX Congresso Brasileiro de Neurologia, 2002, Florianópolis, SC.

21. Agapejev S, Meira DA, Barraviera B, et al. Neurocysticercosis: treatment with albendazole and dexchlorpheniramine. Trans R Soc Trop Med Hyg 1989; 93:377-383.

22. Moreno-Carvalho OA. Neuroesquistossomose. In Tratado de Neurologia, Editora Elsevier, 2013:755-761
23. Arens J, Barnes K, Crowley N, Maartens G. Treating AIDS-associated cerebral toxoplasmosis - pyrimethamine plus sulfadiazine compared with cotrimoxazole, and outcome with adjunctive glucocorticoids. S Afr Med J 2007; 97:956-958.

24. Sonneville R, Schmidt M, Messika J, et al. Neurologic outcomes and adjunctive steroids in HIV patients with severe cerebral toxoplasmosis. Neurology 2012;79:1762-1766.

25. Perini GF, Campregher PV, Santos FPS, Hamerschlak N. Primary central nervous system lymphoma: what a neurologista/neurosurgeon should know. Arq Neuropsiquiatr 2013;71:254-257.

26. Marra CM. Acute Encephalitis. 65th American Academy of Neurology Meeting, 2013.

27. Tan K, Roda R, Ostrow L, et al. PML-IRIS in patients with HIV infection: clinical manifestations and treatment with steroids. Neurology 2009; 72:1458-1464.

28. Berger JR. Steroids for PML-IRIS: a double-edged sword? Neurology 2009;72:1454-1455. 